\title{
QURANIC ADVOCATION OF HONEY CONSUMPTION AND ITS APPLICATION TOWARDS MEMORY ENHANCEMENT(")
}

\author{
Mohd Amiruddin Kamarulzaidi ${ }^{1}$, M.Y. Zulkifli Mohd. Yusoff ${ }^{2}$
}

\& Durriyyah Sharifah Hasan Adli ${ }^{3}$

\begin{abstract}
Over the years honey is not only considered as a natural sweetener, but it is also regarded as a healthy food. Honey meets the requirements as halal (lawful) and tayyiban (good), as mentioned in the Quran. However, very few studies have focused on the effect of honey on memory, either from a scientific perspective or Islamic tradition. This paper looking at the benefits of honey on the memory. The information presented in this paper will look at the benefits of honey on facilitating memory which is made available through a content analysis of scientific references and traditions of Islam. In addition to scientific research reports laboratory studies from the group also become part of the resources for the scientific perspective on honey consumption for this purpose. The Quran, hadith and Islamic scholars writings made up the main source for Islamic perspective on the matter. Honey is highly regarded to the Muslim community as exemplied by the specific mentions in surah al-Nahl (chapter on Bees). Verses 68 and 69 of surah al-Nahl referred to various colors of honey produced by bees with nests in different places. Also mentioned is about the ability of honey as a remedy for various ailments. There are also hadith eluding to related practices using honey by the Prophet as well as recommendations for health problems. Some Islamic scholars, such as al-Zuhri, recommended honey for its good effects on memory. Our laboratory studies proved the benefits of honey on spatial memory (memory with regards to space). A local honey, honey Tualang, was found to have increased spatial memory of rats, especially working memory (short term memory) compared to the reference memory (long term memory). Thus, both the perspectives of Islam and science are in agreement that honey can play a positive role in human health care.
\end{abstract}

Keywords: Honey, Memory, Islamic Medicine, Natural Resources, Tualang honey.

\footnotetext{
(") This article was submitted on: 06/10/2013 and accepted for publication on: 11/06/2014.

1 Mr. Muhammad, Institute of Graduate Studies, University of Malaya (UM), K.L, Email: mohdamiruddin0117@gmail.com

2 Prof. Dr. Zulkifli, Academy of Islamic Studies, (UM), K.L, Email: zulkifliy@gmail.com

${ }^{3}$ Miss. Duriyyah, Faculty of Science, (UM), K.L, Email: durriyyah@um.edu.my
} 


\subsection{INTRODUCTION}

Food is the source of energy for human. In the Islamic tradition, halal food (lawful according to Islamic tradition) and good food are espoused in the Quran, as stated in verse 168 of surah al-Baqarah (chapter 2):

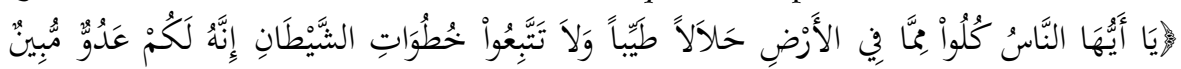

$O$ mankind, eat from whatever is on earth [that is] lawful and good and do not follow the footsteps of Satan. Indeed, he is to you a clear enemy."

Hence, from this verse the consumption of non-halal food is considered not a good act and is like following in the footsteps of Satan. This verse serves as a warning for people not to follow the footsteps of Satan who are enemies mentioned in the same sentence.

An Islamic scholar, Imam Ibn Kathir in his Tafsir al-Qur'an al-Azim, viewed that 'good' food means food which has the taste to one's liking, in addition to not having adverse effects on one's physical and mental (Zainal Abidin, 2007).

There are numerous types of food recommended in Islam as being good for the memory. These foods were mentioned in the Quran, hadith and writings of Islamic scholars, including honey, raisins, dates and saffron. Surah al-Nahl, or 'Bee', chapter which is the 16th chapter in the Quran mentions the production of honey by bees and its ability to "heal" (Abu Maula, Abu Hana dan Agus Irawan, 2009).

In view of the importance of honey as mentioned in the Quran, this paper focused on the recommendation and analyzes the support of scientific research. Also discussed is the effect Tualang honey, a local honey, to the memory. One of the problems related to human health addressed by many scientists is associated with memory. Hence, this paper addressed the lack of systematic documentation on the assertion that honey could be a facilitator and/or healer of memory-related problems from both the perspectives of Islam and science.

\subsection{METHODOLOGY}

Presented information was obtained through content analysis on science based references and sources of Islamic tradition. The Quran, hadith and the writings 
of Islamic scholars were the sources in getting the Islamic perspective on the use of honey. The Quran is the principal source since Muslims believe that Quran is a revelation from God (Allah SWT), which contained fundamentals of Islamic teachings/ traditions. Research works published in scientific journals as well as laboratory studies were the main sources in acquiring scientific perspective on honey. The process of finding references involved the use of databases such as PubMed, ScienceDirect and Scopus.

Google Scholar search engine was used to search for articles using keywords like "Tualang honey", "honey", "memory", "spatial memory", "radial arm maze" and "Islamic medicine". Information was also obtained from the literature available in the University of Malaya library, for example in the form of books, texts and academic exercises.

Experiments involving behavioral test to assess memory performance of rat was performed to demonstrate the effect of honey on memory.

\subsection{RESULTS AND DISCUSSION}

\subsection{HONEY FROM THE ISLAMIC REFERENCES}

\subsubsection{Recommended Honey Consumption by the Quran}

As stated in verse 15 of surah Muhammad (chapter 47), Allah glorifies honey by His promise of serving it in heaven as a reward to those who are righteous during his life time:

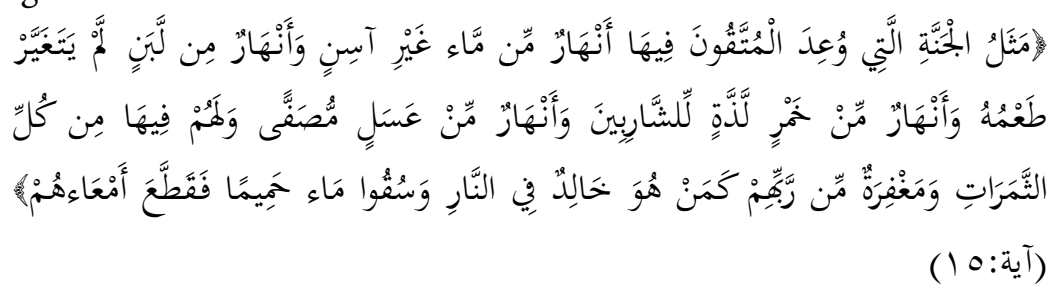

"Is the description of Paradise, which the righteous are promised, wherein are rivers of water unaltered, rivers of milk the taste of which never changes, rivers of wine delicious to those who drink, and rivers of purified honey, in which they will have from all [kinds of] fruits and forgiveness from their Lord, like [that of] those who abide eternally in the Fire and are given to drink scalding water that will sever their intestines?" 
In addition, there exists surah al-Nahl, a chapter in Quran that refers to honey. Surah al-Nahl, the 16th chapter in the Quran, consists of 128 verses and it is considered as a surah Makkiyyah. It was revealed to the Prophet on his return from the battle of Uhud. It is called surah "al-NahP" which means "bees" because in its verse 68, there is a specific mention which means "And your Lord inspired/ taught the bee". It is also called surah "al-Ni'am" which means "many blessings" because there are many mentions on blessings stated inside it (Universitas Islam Indonesia, 1995). More importantly to the topic discussed, is that the Islamic tradition which strongly recommends honey consumption for health is based on verses 68 and 69 of surah al-Nahl (Abu Maula, Abu Hana dan Agus Irawan, 2009). These verses talked about the production of honey by the bees and its ability to heal:

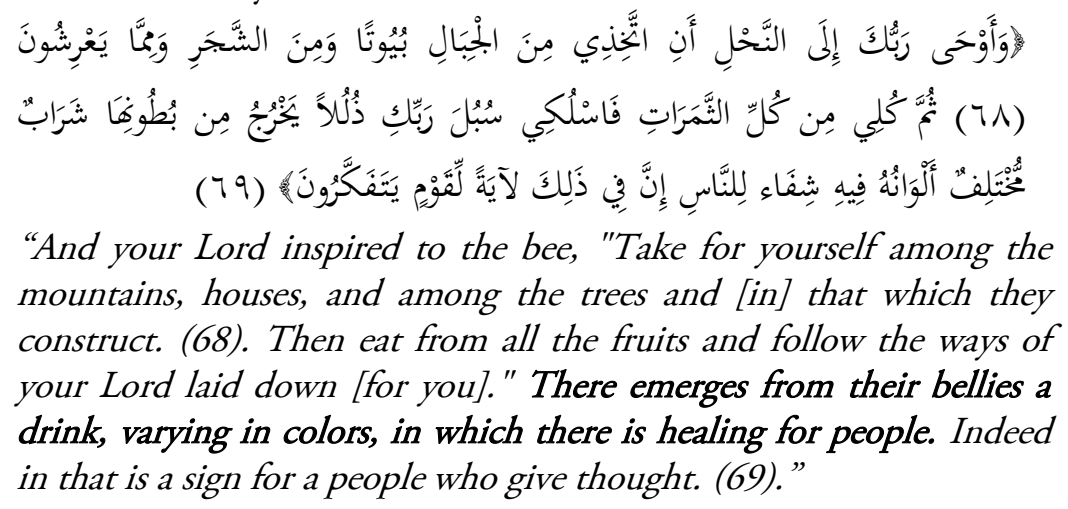
mountains, houses, and among the trees and [in] that which they construct. (68). Then eat from all the fruits and follow the ways of your Lord laid down [for you]." There emerges from their bellies a drink, varying in colors, in which there is healing for people. Indeed in that is a sign for a people who give thought. (69)."

In the earlier verse (verse 68) there is Allah's order to the bees to make its hives in the mountains, on the trees and man-made buildings/ habitations. Pronouncement "اتخذي" in the form of instruction to the bees is in the form of "muannath", which is "female" in nature. This is in agreement to the situation of a colony of bees which is normally led by a queen bee, and that the number of female bees is more than the males (Najib, 2008).

The later verse (verse 69) described the role of bees in the production of honey with the flowers and fruits as food sources. Consequently, the bees produce honey of a variety of colors as also described in verse 69. As it is known, bees actually consume only nectar of flowers from both fruitful and non-fruitful trees. Hence, the honey produced contains a variety of nutrients from diverse plant sources (Najib, 2008). 
A more important point to note is that verse 69 specifically recommends the use of honey for health purposes because Allah SWT ordains it that honey has a healing power to cure various kinds of diseases. However, there is a disagreement among Islamic scholars on the meaning of "containing healing for mankind". Some are of the opinions that dhomir (personal pronouns) for the term"فيه" refers to the Quran as a medicine, but the majority of scholars agreed that dhomir refers to honey as medicine, being a cure for all types of diseases for all people (Najib, 2008). However, according to scholar Ibn Hajar in his book Fath al-Bari the statement "containing healing for mankind" does not actually indicate that honey is suitable for everyone. Instead, its consumption may be unsuitable for those living in the hot climate region (Deuraseh, 2006).

\subsection{Recommended Honey Consumption by the Hadith}

Similar recommendation of honey consumption could also be found in other sources such as hadith (saying and action of Prophet Muhammad SAW). Honey was one of the Prophet's favorite foods as mentioned by a hadith (Muhammad, 1987, 5682), by 'Aisha:

"Prophet was very fond of sweet foods and honey."

Since Prophet Muhammad SAW is the best living human model in the Islamic tradition, this means that developing a liking for honey or regularly consuming honey is advocated in Islam. The intake of honey for health care purposes has to date been practiced since the time of the Prophet and his companions. A few hadith submitted that both the Quran and honey should be used as medicine/ cure to diseases (Muhammad, 1987, 3452):

" Take / use by you two medicines that are honey and the Quran."

There are hadith which specifically mentioned the healing ability of honey to cure human diseases. As found in Sahih Bukhari's al-Tibb, Bab al-Shifa ' $f$ Thalatha, there are two hadith by Ibn 'Abbas on the matter (Al-Bukhari, n.d., 5680, 5681):

"Healing from the disease is by doing three things: drinking honey, cupping and cauterization. But I forbid my followers to cauterize."

"Healing from the disease is by doing three things: cupping, honey, and cauterization. But I forbid my followers to cauterize."

Specifically, Ibn Hajar narrated that the Prophet Muhammad SAW listed only these three physical methods as the principle treatments for a disease. However, 
Islamic scholars interpreted these treatments in the hadith as focusing only on blood related diseases, which were prominent among the Arabs at that time.

\subsection{Honey Consumption to Improve Memory in the Islamic Tradition}

To Muslims, memory is one of the blessings from Allah the Almighty. Without it man cannot lead a quality life since memory is a necessity in all aspects of life, e.g. daily activities, remembering different aspects of religious rituals (such as prayers, ablutions), remembering a person's face or name, and remembering an event. Memory is significantly used during the learning process to remember facts and new information, such as memorizing the verses of Quran and hadith. The deterioration of memory is mentioned a few times in Quran, for example in verse 70 of surah al-Nahl (chapter 16):

\section{"And Allah created you; then He will take you in death. And among you is he who is reversed to the most decrepit [old] age so that he will not know, after [having had] knowledge, a thing. Indeed, Allah is Knowing and Competent."}

Islamic scholars have suggested consumption of honey for memory improvement, for example Az-Zuhri said, "Eat honey, because it is good for memory." He also stated that the best type of honey is the one that is pure, most light in its color, and most sweet. In addition, honey collected from the trees and the mountains is deemed better than the honey harvested from the beehives provided by humans, such as in bee farms. In addition, the quality of honey varies correlating to the areas where the bees collect the nectar (Ibn AlQaiyim Al-Jauziyah, 1997).

According to Ibn Sina in his Qanun fi Tibb honey is good in treating wounds and ulcers, brightening the eyesight, as well as food to sharpen the mind (Ibn Sina, 1999). In addition, honey has the potential to improve blood circulation and provide greater supply of oxygen throughout the body, thus also to the brain (Deuraseh, 2006).

Both al-Kindi (a well known Islamic scholar) and Epahasus of Rufus (a doctor at the time of the ancient Greeks) suggested that cold and damp conditions could be damaging to the memory (Ullman, 1997). Scientific basis for such an assertion has not been established, although a few disturbances of the nervous system has been associated to the winter season (Morishima et al. 2002). 
Two concoctions with honey had each been suggested by two Islamic scholars to treat deteriorating memory, improve memory and sharpen the mind (Table 1). Al-Kindi in the book Aqrabadhin (Levey, 1966) and Ibn al-Jazzaar in the book Zad al Musafir wa - qut al hadir (Pormann and Savage-Smith, 2007), each gave recipes for the concoctions with some peculiar ingredients.

Table 1: Recipe and prescription involving honey

Recipe and prescription by al-Kindi for concoction to treat memory deterioration

1) Sieve with silk fabric then weigh two parts of celery seed and one part of new sweet flag (Dhareerah).

2) Mix with cow ghee and kneaded with honey, with the ratio of 1:5, respectively.

3) Mixture to be placed in a glazed pot or a glass container and buried in barley for 40 nights, before removed.

Prescription: One and a half dirhams for the first day and to be increased in small amounts each day until dosage is to become 2 mithqals on the seventh day.

*1 dirham=3.2 gram, 1 mithqals= $4.25 \mathrm{gram}$

Recipe and prescription by Ibn al-Jazzaar for concoction to improve memory

1) The following ingredients are to be pulverized, sieved, mixed together and kneaded with honey of wild thyme.

- Seven mithqals each of Chinese cinnamon, sweet cost, Indian spikenard, saffron, fennel seeds, ginger, dried mint leaves, wild mountain thyme, mountain mint, cinnamon bark,

- Four mithqals each of Indian 'malabathron', long pepper, white pepper, black pepper, asarabacca, plum seeds, cultivated caraway, cloves, galingale, and wild carrot.

- Two mithqals each of pellitory, cardamon, radish seeds, and turnip seeds.

- Eleven mithqals each of hulled sesame, shelled walnuts, shelled pistachios, shelled fresh almonds, pinenuts and sugar candy.

2) The well-blended remedy is to be kept in a container that has smooth interior and fumigated with Indian aloes.

Prescription: The concoction is to be taken before and after meal in the size of a walnut.

*1 dirrham=3.2 gram, 1 mithqals=4.25 gram

\subsection{HONEY FROM THE SCIENTIFIC RESEARCH}

As commonly known, honey is naturally produced by bees (Apis sp.) that suck nectar from plants. Nectar is a liquid produced by nectaris cells found in flowers. Nectar content varies, depending on the species of plants and the environment surrounding the plants. For example, sugars, amino acids and other acids, proteins, lipids, and minerals contained in the nectar vary, 
depending on the source of nectar. Ripening nectar into honey is a combination of two processes, namely the conversion of sucrose into glucose and fructose, as well as the evaporation of excessive water (Ball, 2007). Table 2 shows the average content found in honey.

Table 2: Average composition in honey with $\mathrm{pH} 3.9$ (data in g/100 g) [7-10]

\begin{tabular}{|l|c|}
\hline \multicolumn{1}{|c|}{ Component } & Average (\%) \\
\hline Water & 17.2 \\
\hline Fructose & 38.19 \\
\hline Glucose & 31.28 \\
\hline Sucrose & 1.31 \\
\hline Disaccharides, calculated as maltose & 7.31 \\
\hline Higher sugars & 1.5 \\
\hline Free acid as gluconic & 0.43 \\
\hline Lactone as gluconolactone & 0.14 \\
\hline Total acid as gluconic & 0.57 \\
\hline Ash & 0.169 \\
\hline Nitrogen & 0.041 \\
\hline Mineral & 0.2 \\
\hline Amino acids, proteins & 0.3 \\
\hline \multicolumn{2}{|c|}{ *Adapted from (Alvarez-Suarez et al., 2010) } \\
\hline
\end{tabular}

The use of honey in Malaysia is gaining wide acceptance. With the availability of various types of honey in the market, Malaysians are increasingly realizing the importance of honey in health care. However, not all honey available in the market is natural honey. Natural local honey is very difficult to obtain. A study conducted in the Faculty of Medicine, University of Malaya demonstrated that authenticity of honey could be distinguished based on the main sugar content. Characterisation of honey could be based on criteria such as fructose/glucose ratio, total reducing sugars, sucrose percentage in the honey sample and analysis of chromatogram pattern (M. Yusof et al., 2010).

Some examples of natural local honey is Gelam honey, Nenas honey, Tualang honey, Coconut honey, Belimbing honey and Durian honey (Rozaini et al., 2004; Ainul Hafiza et al., 2005). Tualang honey collected from hives of bees (Apis sp.) which build their nests in the Tualang tree (Koompassia excelsa) (Tan et al., 2009). In Malaysia, Tualang honey is commonly used in food and health product (Che Ghazali, 2009).

The study performed by Kishore and colleagues (2011) showed Tualang honey has the highest total phenolic content compared with Gelam honey, Indian 
forest honey and honey Pineapple. The data obtained show Tualang honey has better antioxidant effect against reactive oxygen species compared with the other three honey studied. Phenolic content and other compounds found in honey contribute to free radical scavenging and antioxidant activities that give positive impact on human health (Kishore et al., 2011).

The study conducted by Khalil and colleagues (2012) also studied total polyphenol and flavonoid content and antioxidant properties of 11 samples of honey Tualang. Tualang honey samples (AgroMas ${ }^{\circledR}$ ) was supplied by FAMA (Federal Agricultural Marketing Authority, Kedah, Malaysia) collected by honey collectors from 11 different areas in Kedah Rainforest. Tualang honey samples then compared with tropical honey Borneo, which is another type of honey that is available in Malaysia. The results showed that on average, the total polyphenol and flavonoid content in processed Tualang honey honey is higher than Borneo tropical honey. Total phenolic content was found higher than flavonoids, but this number can vary depending on the origin source of honey and flowers. Tualang antioxidant content of honey was higher than Borneo tropical honey (Khalil et al., 2012).

\subsubsection{Memory from the Scientific Perspective}

The word cognitive derives from the word cognition. The word cognition itself refers to the action to find out or obtain the information/ knowledge. Human acquires information/ knowledge through focusing attention to events occurring in the surrounding and storing them in the brain. The study about cognition is the study of internal processes that produce information and how this information is developed. In a study involving cognitive tradition, the emphasis would be on concentration, perception and memory (Gordon, 1989). Concentration, perception and memory are classified as basic cognitive functions; while the ability to process language and decision making are classified as high-level cognitive functions (Glisky, 2007).

Learning and memory are two different things, but they are closely related or are interconnected with one another (Gordon, 1989). Learning is the process of acquiring knowledge/ new information; a process that elicits the onset of memory formation. Memory is formed by what one has learned; the retention or storage of the knowledge/ information. At the same time, one also needs a memory to remember what one has learned.

Many of the experiments related to memory and learning were carried out using the behavioral approach with experimental animals, especially rats. There is a 
diversity of experimental methods assessing animal learning and memory skills. Among the experimental methods carried out to assess memory, particularly spatial memory in rat, used devices such as the Radial Arm Maze (RAM), Y Maze and Morris Water Maze.

\subsubsection{Facilitatory Role of Honey in Improving Memory from the Scientific Perspective}

Antioxidant activity/ capacity is the ability and potential to reduce oxidative reactions in food system and human health (Alvarez-Suarez et al., 2010). This oxidative reaction causes a reaction that can damage the food and cause illnesses such as cancer and other chronic diseases. Honey is one of the naturally occurring sources of antioxidants; thus, honey could be part of the brainhealthy diets essential for brain functions, e.g. giving positive effect on memory related activities (Chepulis et al., 2009). Honey contents like sugars (includes glucose, fructose), a variety of phytochemicals (includes polyphenol) and others such as organic acids, vitamins, enzymes (includes glucose oxidase, catalase), $\alpha$ tocopherol, ascorbic acid, peroxides, flavonoids, phenolic acids, carotenoid derivatives (e.g. $\beta$-carotene), Maillard reaction products, amino acids and proteins may serve as sources of dietary antioxidants (Gheldof et al., 2002). Its wide range of antioxidant activity also depends on the source of the nectar (Hegazil and Abd El-Hady, 2007) and the environment where honey is produced (Kesić et al., 2009). In addition, the presence of materials other than phenolic compounds such as vitamins $\mathrm{C}, \mathrm{E}$ and carotenoids could also influence the antioxidant activity.

The antioxidative activity of honey polyphenols can be measured in vitro by comparing the oxygen radical absorbance capacity (ORAC) with the total phenolics concentrations (Gheldof et al., 2003). Oddly, the absence of antioxidant activity in some honey had also been reported (Al-Mamary et al., 2002). Since different antioxidant compounds have different oxidative effects, The reported results probably involved honey which contained different types of phenolic compounds that did not show antioxidant properties.

Another feature of honey that may have positive effect on memory is its glucose content. Glucose uptake can improve spatial memory and plays an important role in assisting the process of memory formation. This is due to the release of epinephrine, which eventually increases the production of acetylcholine in the hippocampus and amygdala of the brain. Thus, glucose restores the cellular energy level that is used in the process of learning (Dash et al., 2006). 
According to a study the intake of honey for a long time could reduce anxiety and improve spatial memory in middle age rats (Chepulis et al., 2009). In the study, for 52 weeks two groups of two-month-old rats were given food containing $10 \%$ honey and $7.9 \%$ sucrose, respectively. Y Maze test and the Object Recognition test were conducted to test memory in rats. Rats fed with honey showed better performance in the Y maze test compared to the group of rats fed with sucrose. Group fed with sucrose showed poor performance in this test.

Our own preliminary study examined the effect of honey on memory using RAM which had a center platform with eight arms radiating out from it (Sahak, 2011). RAM has often been used as a paradigm to assess working and reference memory in rats, demonstrating the phenomenon of "place learning." To date, the model is widely used in researches, albeit it had been modified into several version, thus, slightly different from the original version, e.g. the use of external stimuli associated with particular locations to discriminate among the locations (Dubreuil et al., 2003).

Our study demonstrated that honey showed positive effect on spatial memory of adult rat. In the study, twenty adult (7-8 weeks) male rats were force-fed daily with $70 \%$ Tualang honey and $0.9 \%$ saline (control) $1 \mathrm{ml} / 100 \mathrm{~g}$ body weight for three months. Rats which were given behavioral tests to assess spatial memory were divided into two groups: (a) Tualang honey, or (b) saline. Tests on rat memory were performed weekly by using RAM. During the weekly SMP (Spatial Memory Performance) assessment with baited and non-baited arms established in RAM, a one day food-deprived rat was placed in the maze center and allowed to explore the arms for food within 3 minutes.

In general, compared with the saline group, honey group showed a significant decrease $(\mathrm{p}<0.05)$ in the parameters that describe the positive effects of Tualang honey in the last two phases of the experiment (Kamarulzaidi, 2012). The findings suggest that honey Tualang significantly improve learning and / or memory after 7 weeks of use. This effect remained for the next 12 weeks of use. Tualang honey showed a positive effect in improving working memory (short term memory) compared with reference memory (Long Term Memory).

\subsection{CONCLUSION}

Honey has been used as a source of nutrients and alternative medicine to treat the disease since the beginning of humankind. Islamic reference specifically Qur'an, emphasizes taking honey for health reasons. Although no 
recommendations to take honey for memory specifically mentioned in the Quran, but it is stated by the hadith and Islamic scholars view. Results of scientific studies proving especially Tualang honey not only treat various diseases, but also give positive effect on the cognitive function, especially memory.

\section{ACKNOWLEDGEMENTS}

The authors wish to thank the University of Malaya for providing financial support through research grant (RG202/11AFR); Centre for Foundation Studies in Science, University of Malaya for access to the animal house; and Neuroscience Research Group, University of Malaya for technical support and assistance. This study was partly presented at the International Seminar on alQuran in Contemporary Science (SQ 2012) and International Conference on Traditional Medicine (CONTRAMED 2011).

\section{REFERENCES:}

Abidin, D. Z. (2007). Quran Saintifik Meneroka Kecemerlangan Quran daripada Teropong Sains. Kuala Lumpur: PTS Millenia Sdn. Bhd.

Ainul Hafiza A.H., Yusof, N., dan Maimon, A. (2005). Potensi Madu Tempatan Malaysia sebagai Agen Antibakteria [abstrak]. Sains Malaysiana, 34 (1): 17-20.

Al-Bukhari. n.d. al-Jami' al-Sahih lil Bukhari. Kaherah: Maktabah Salafiyah.

Al-Mamary, M., Al-Meeri, A. and Al-Habori, M. (2002). Antioxidant Activities and Total Phenolics of Different Types of Honey. Nutrition Research, 22: 1041-1047.

Alvarez-Suarez, J.M., Tulipani, S., Romandini, S., Bertoli, E. and Battino, M. (2010). Contribution of Honey in Nutrition and Human Health: A Review. Mediterr J Nutr Metab, 3: 15-23.

Ball, D.W. (2007). The Chemical Composition of Honey. Journal of Chemical Education, 84(10): 1643-1646.

Che Ghazali, F. (2009). Morphological characterization study of Malaysian honey -a vpsem, edx Randomised Attempt. Annals of Microscopy, 9: 93102.

Chepulis, L.M., Starkey, N.J., Waas, J.R. and Molan, P.C. (2009). The Effects of Long Term Honey, Sucrose or Sugar-Free Diets on Memory and Anxiety in Rats. Physiology \& Behavior, 97: 359-368.

Dash, P.K., Orsi, S.A, and Moore, A.N. (2006). Spatial Memory Formation and Memory-Enhancing Effect of Glucose Involves Activation of the 
Tuberous Sclerosis Complex-Mammalian Target of Rapamycin Pathway.

The Journal of Neuroscience, 26(31): 8048-8056.

Deuraseh, N. (2006). Health and Medicine in the Islamic Tradition Based on the Book of Medicine (Kitab al-Tibb) of Sahih Bukhari.

Dubreuil, D., Tixier, C., Dutrieux, G. and Edeline, J. M. (2003). Does the

Radial Arm Maze Necessarily Test Spatial Memory? Neurobiology of Learning and Memory, 79: 109-117.

Gheldof, N., Wang, X. H. and Engeseth, N. J. (2002). Identification and Quantification of Antioxidant Components of Honeys from Various Floral Sources. Journal of Agricultural and Food Chemistry. 50(21): 5870-5877.

Gheldof, N., Wang, X. H. and Engeseth, N. J. (2003). Buckwheat Honey Increases Serum Antioxidant Capacity in Humans. J Agric Food Chem, 51:1500-5.

Glisky, E. L. (2007). Brain Aging: Models, Methods and Mechanisms. Boca Raton (FL): CRC Press.

Gordon, W. C. (1989). Learning and Memory. California: Brooks/Cole Publishing Company.

Hegazi1, A. G. and Abd El-Hady, F. K. (2007). Influence of Honey on the Suppression of Human Low Density Lipoprotein (LDL) Peroxidation (In vitro). eCAM, 6(1), 113-121.

Ibn Al-Qaiyim Al-Jauziyah. (1997). Tibb Nabawi. Beirut: Resalah Publishers. Ibn Sina. (1999). Qanun fi Tibb. Beirut: Dar al-Kutub al-Ilmiyah.

Kamarulzaidi, M.A., Mohd. Yusoff, M.Y.Z. dan Hasan Adli, D.S. (2012).

Effects of Tualang Honey Intake on Spatial Memory of Adult Rat.

Proceeding of The International Neuroscience Symposium, Universiti Malaysia Sabah, Sabah.

Kesić, A., Mazalović, M., Crnkić, A., Ćatović, B., Hadžidedic, Š., and Dragošević, G. (2009). The Influence of L-ascorbic Acid Content on Total Antioxidant Activity of Bee-honey. European Journal of Scientific Research, 32(1): 95-101.

Khalil, M.I., Sulaiman, S.A., Alam, N., Ramli, N., Mohamed, M., Bai'e, S. dan Gan, S.H. (2012). Content and Antioxidant Properties of Processed Tualang Honey (Agromas ${ }^{\oplus}$ ) Collected from Different Regions in Malaysia. International Journal of Pharmacy and Pharmaceutical Sciences, 4 (3): 214-219.

Kishore, R.K., Ahmad Sukari, H., M.S. Nurul Syazana dan K.N.S. Sirajudeen. (2011). Tualang has Higher Phenolic Content and Greater Radical Scavenging Activity Compared with Other Sources. Nutrition Research, 31: 322-325. 
Levey, M. (1966). The Medical Formulary or Aqrabadhin of Al-KindiTranslated with a Study of its Materia. Wisconsin: The University of Wisconsin Press.

M. Yusof, M.A., Enchang, F. K. and Mohd Yusoff, K. (2010). Characterization of Major Sugars in Honey as Purity Indicator [abtract]. Journal of ApiProduct and ApiMedical Science, 2(1): 31-60.

Maula, A., Hana, A. and Irawan, A. (2009). Ensiklopedia Kemukjizatan Sains Dalam Al-Quran and Sunnah. (Terjemahan daripada buku Mausu'ah AlI'jaz Al-'Ilmi Fi Al-Quran Al-Karim Wa As-Sunnah Al-Muthahharah oleh Yusuf A-Hajj Ahmad. Kuala Lumpur: Al-Hidayah Publication.

Morishima, T., Togashi, T., Yokota, S., Okuno, Y., Miyazaki, C., Tashiro, M., Okabe, N. and the Collaborative Study Group on Influenza-Associated Encephalopathy in Japan. (2002). Clinical Infectious Diseases: Encephalitis and Encephalopathy Associated with an Influenza Epidemic in Japan. Influenza-Associated Encephalopathy, 35:512-517.

Muhammad bin Yusuf bin Isa. 1987. Jami' al-Syamli fi hadisi Khatim al-Rasul SAW. Beirut: Dar al-Kutub al-'Ilmiah.

Najib, A.K. (2008). Madu Lebah Ubat yang Turun Bersama Wahyu. Selangor: Pustaka Ilmi.

Pormann, P.E. and Savage-Smith, E. (2007). Medieval Islamic Medicine. Edinburg: Edinburgh University Press Ltd.

Rozaini, M.Z., Zuki, A.B.Z., Noordin, M., Y. Norimah dan Nazrul Hakim, A. (2004). The Effects of Different Types of Honey on Tensile Strength Evaluation of Burn Wound Tissue Healing. Intern J Appl Res Vet Med, 2 (4).

Rozaini, M.Z., Zuki, A.B.Z., Noordin, M.M., Yusof, N. and Nazrul Hakim, A. (2004). The Effects of Different Types of Honey on Tensile Strength Evaluation of Burn Wound Tissue Healing. International Journal of Applied Research in Veterinary Medicine, 2 (4): 290-296.

Sahak, M.K.A. (2011). Effects of a Local Honey (Nenas honey) on Spatial Memory of Male Adult Rats, B.Sc. Thesis, University of Malaya.

Tan, H.T., A Rahman, R., Gan, S.H., Halim, A.S., Hassan, S.A., Sulaiman, S.A., dan Kirnpal-Kaur, B. S. 2009. The antibacterial properties of Malaysian Tualang honey against wound and enteric microorganisms in comparison to Manuka honey. BMC Complementary and Alternative Medicine, 9: 34 .

Ullman, M. (1997). Islamic Medicine. Edinburgh: Edinburgh University Press. Universitas Islam Indonesia (1995). Al-Quran dan Tafsirnya, PT. Yogyakarta: Dana Bhakti Wakaf. 